\title{
Diyatomit Agregalı Blok Elemanların Yüksek Sıcaklık ve Donma- Çözülme Etkisinde Bazı Fiziko-Mekanik Özelliklerinin Araştırılması
}

\author{
Hakan AKBABA*1 \\ ${ }^{1}$ Uşak Üniversitesi, Banaz Meslek Yüksekokulu, Inşaat Teknolojisi Bölümü, Uşak
}

Geliş tarihi: 22.03 .2020

Kabul tarihi: 30.07 .2020

\section{$\ddot{O} z$}

Çalışmada yüksek puzolanik özelliğe sahip olan diyatomitin, hafif beton blok üretiminde kullanılabilirliği araştırılmıştır. Çimento dozajı $\left(220 \mathrm{~kg} / \mathrm{m}^{3}\right)$ ve su/çimento oranı $(0,15)$ sabit olmak üzere, farklı tane dağılımlarına (granülometri) sahip agregalar kullanılarak üretilen 10x10x10 cm ebatlarındaki küp numunelerin, yüksek sıcaklık ve donma-çözülme etkisi sonrasında bazı fiziksel ve mekanik özelliklerindeki değişiklikler incelenmiştir. Deneysel çalışmalar için agregalar 0-4 mm (ince), 4-8 mm (orta) ve $8-16 \mathrm{~mm}$ (iri) tane dağılım oranına sahip 5 farklı seride üretilmiştir. 28 günlük sertleşmiş numuneler üzerinde birim hacim ağırlık, porozite, ultrases, basınç dayanımı ve elastisite modülü değerleri belirlenerek, yüksek sıcaklık ve donma-çözülme etkisi sonrasında numunelerde oluşan fiziksel değişimler kaydedilmiş̧tir. Deney sonuçlarında, birim hacim ağırlık değerlerinin $1182,33-1273,37 \mathrm{~kg} / \mathrm{m}^{3}$ arasında değişiklik gösterdiği, donma-çözülme sonrasında, ufalanma ve parçalanma ile ortalama \%8,53 kütle azalışının yanı sıra, basınç dayanımında da azalış gözlenmiştir. Yüksek sıcaklık etkisi $\left(600{ }^{\circ} \mathrm{C}\right)$ ile ortalama \%7,9 kütle azalı̧̧ı oluşurken, basınç mukavemetinde ise ortalama \%55,22 oranında artış gözlenmiştir.

Anahtar Kelimeler: Diyatomit, Hafif blok eleman, Yüksek sıcaklık (yangın), Donma-çözülme

\section{Investigation of Some Physico-Mechanical Properties of Diatomite Aggregate Block Elements in High Temperature and Freezing-Thawing Effect}

\begin{abstract}
In this study, the use of diatomite, which has a high pozzolanic property, in light concrete block production was investigated. After the high temperature and freeze-thaw effect of some 10x10x10 cm cube samples produced using aggregates with different grain distributions (granulometry) with cement dosage $\left(220 \mathrm{~kg} / \mathrm{m}^{3}\right)$ and water/cement ratio $(0.15)$ constant. Changes in properties are examined. For experimental studies, aggregates were produced in 5 different series with 0-4 $\mathrm{mm}$ (fine), 4-8 $\mathrm{mm}$ (medium) and 8-16 mm (large) grain distribution ratio. Physical changes occurred in samples after high temperature and freeze-thaw effect were determined by determining unit volume weight, porosity, ultrasound, compressive strength and elasticity module values on 28 days of hardened samples. In the
\end{abstract}

*Sorumlu yazar (Corresponding author): Hakan AKBABA, hakan.akbaba@usak.edu.tr 
results of the experiment, it was observed that the unit volume weight values varied between 1182,33$1273,37 \mathrm{~kg} / \mathrm{m}^{3}$, after freezing-thawing, a decrease in compressive strength was observed along with an average $8.53 \%$ mass decrease with crumbling and breaking down. While an average mass decrease of $7.9 \%$ occurred with high temperature effect $\left(600{ }^{\circ} \mathrm{C}\right)$, an average increase of $55.22 \%$ was observed in compressive strength.

Keywords: Diatomite, Lightweight block materials, High temperature (fire), Freeze-thaw

\section{GíRiş}

Ülkemizde bol rezerve sahip olan hammadde kaynaklarından yararlanılarak üretilebilecek yeni yapı malzemelerinin araştırılması büyük önem taşımaktadır. Özellikle hafif yapı malzemesi alanında fiziksel koşullara karşı dayanıklı, ekonomik, sağlıklı ve kolay elde edilip kullanılabilen malzemelerin geliştirilmesi hedeflenmektedir [1,2]. Yapılan çalışmalarda hafif beton üretimi, taşıyıcı olmayan duvar malzemesi, bağlayıcı katkı maddesi olarak kullanımı ve mevcut özelliklerinin iyileştirilmesi için çeşitli deneysel çalışmalar yapılmaktadır. Günümüz inşaat teknolojisinde kullanılan konstrüktif hafif yap1 elemanları endüstriyel hammaddelerden üretilmektedir. Endüstriyel hammadde tanımı; kumçakı1, kireçtaşı, killer, zeolit, talk, vermikulit, sepiolit, diyatomit, grafit ve silikadan; manyezit, perlit, pomza, feldispat, mika, wollastonit, barit, florit doğal taşlar ve gübreye kadar her çeşit mineral ve kayaçları kapsamaktadır. Türkiye, karmaşık jeolojik yapısı nedeniyle farklı tiplerde, önemli endüstriyel hammadde yataklarına sahiptir [3-6].

İnşaat teknolojisinde yapı statiği ve dinamiği açısından hafifliğin yanı sıra, yapıda bu hafifliği sağlayacak olan temel bileşenlerin standartlara uygun özellikler gösteren hammaddelerden üretilmeleri de son derece önemlidir. Günümüzde hafifliği sebebi ile farklı tanımlar altında değişik doğal ve/veya suni yapı malzemeleri inşaat sektöründe kullanılmaktadır. Ancak bazı tür malzemelerin kullanımları, zaman içinde kullanım yerine bağlı olarak gelişen olumsuzluklar nedeniyle sorun oluşturmaktadır. Bu bakımdan inşaat sektöründe, değișen atmosferik koşullara karşı dayanıklı, zaman içinde teknolojik özellikleri değişmeyen hafif yapı elemanı kullanımı ve imalat sektöründe buna bağlı ürün geliştirme çalışmaları hız kazanmıştır. Yapılarda kullanılacak çağdaş duvar malzemesinin üretilmesi, ülkemiz ihtiyaçlarına cevap verebilecek nitelikte geliştirilmesi, iç-dış ortam şartlarına, 1S1 ve ses yalıtımı özeliklerine sahip, fiziksel, kimyasal, biyolojik etkilere dayanıklı, yani yapı fiziği kurallarını yerine getirebilen bir yapı malzemesi olması gerekir [7,8].

Pomzaya benzer şekilde yüksek gözenekliliğe sahip olan diyatomit, hafif beton üretiminde agrega olarak kullanımı araştırılan kayaçlardan biridir. Diyatomit, su yosunları sinıfindan tek hücreli mikroskobik diyatomların silisli kavkılarının birikmesi sonucu oluşmuş organik tortul kayaçtır. Diyatomit, volkanik bölgelere yakın, tatlı ve tuzlu göl veya deniz sularında yaşayan tek hücreli, mikroskobik, silis yapılı çift karapaslı esmer bir yosun çeșidi olan diyatomelerin ölmesi ve silisli kabuklarının bir araya toplanmasi sonucunda meydana gelen bir mineral olarak da tanımlanmaktadır. Diyatomitin dünyada kullanımı çok eski zamanlara dayanmaktadır. MS 500'lü yıllarda İstanbul'da inşa edilmiş olan Ayasofya Camii'nin kubbesinde hafifliğinden dolayı diyatomit tuğla kullanıldığı bilinmektedir. Buna rağmen, diyatomitin Batı Avrupa'da yalıtım amaçlı olarak kesme blok ve tuğla şeklinde ticari anlamda kullanımı 1800'lü yılların ortasına rastlamaktadır [9-11].

Yapıda kullanılan malzemelerin ağırlığının azalmasına bağlı olarak temele aktarılan yükün azalacağı ve yaklaşık \%15-20 oranında inşaat demiri tasarrufunun yanı sira 1si ve ses yalıtımı olarak normal betona göre yaklaşık olarak dört kat fazla yalıtım kalitesi sağlanabilmektedir. Pomza ve ucu kül kullanılarak üretilen hafif betonların agresif şartlar altındaki mekanik özelliklerinin bilinmesi bu tür betonların agresif şartlara maruz kalması durumunda mekanik özeliklerinde 
olabilecek olumsuzlukların bilinmesi ve tedbir alınması yapı güvenliği açısından önemlidir.[12]

Dünyada sanayinin birçok dalında yaygın olarak hammadde şeklinde kullanılan diyatomit, yap1 sektöründe de çeşitli bağlayıcılar ile 1sı yalıtım amaçlı blok (tuğla) üretiminde kullanılmaktadır. Ancak bilinen uygulamalardan farklı olarak diyatomit esaslı hafif yapı elemanı üretiminde, üreformaldehit bağlayıcı olarak denenmiş ve olumlu sonuçlar alınmıştır. $\mathrm{Bu}$ özelikleriyle bu elemanların hafif yapi elemanı olarak kullanılabileceği sonucuna varılmıştır [6].

Şehirlerimizdeki hızlı sanayileşmeye bağlı oluşan nüfus artışı paralelinde ihtiyaç duyulan konut ve bölme duvar ihtiyacını temin eden tuğla üreticileri, hammadde bulabilmek için zengin tarım topraklarını yok etmektedirler. Çalışma, yapılar için gerekli duvar ve bölme eleman malzemesi temininde sık kullanılan tuğlaya alternatif olarak, üretimi kolay, hammadde sıkıntısı olmayan, ekonomik, 1sı ve ses yalıtımı yüksek, sağlıklı yapı bloklarının üretilmesine katkı sağlayacaktır.

\section{MATERYAL VE METOD}

\subsection{Kullanılan Malzemeler}

\subsubsection{Diyatomit}

Diyatomitin çimento katkı maddesi, filtrasyon malzemesi, puzolanik malzeme ve yalıtım malzemesi olarak çeşitli endüstriyel alanlarda kullanılabilmektedir [13].

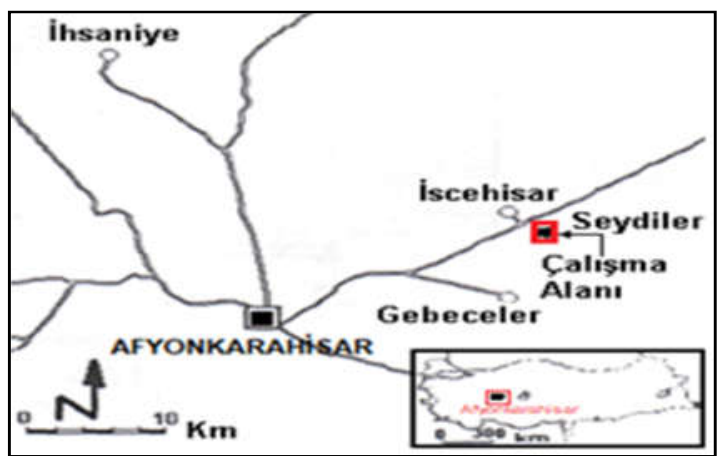

Şekil 1. Diyatomit kayaçlarının temin edildiği bölgenin konumu
Çalışmada agrega olarak kullanılan diyatomit Afyonkarahisar-Ankara karayolu 24. km'si üzerinde bulunan Seydiler kasabası mevkisinden temin edilmiştir (Şekil 1). Blok halindeki kayaçlar taşınabilir büyüklüğe $\quad-0,2-30 \mathrm{~kg}-$ getirilerek, çalışmanın yapılacağı laboratuvar ortamına taşınmış, sonrasında kırma ve eleme işlemlerinden geçirilerek, deneylerde kullanılacak diyatomit agregası tane büyüklüğü olan $0-4 \mathrm{~mm}$ (ince), 4-8 mm (orta) ve 8-16 mm (iri) tane sinıfları [14] elde edilmiştir (Şekil 2 ve Şekil 3).

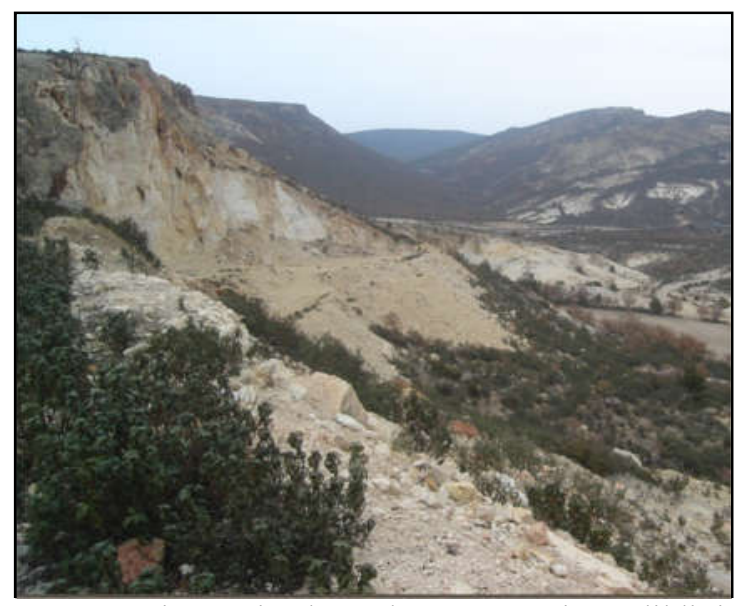

Şekil 2. Diyatomit kayaçlarının temin edildiği bölge (genel görünüm)
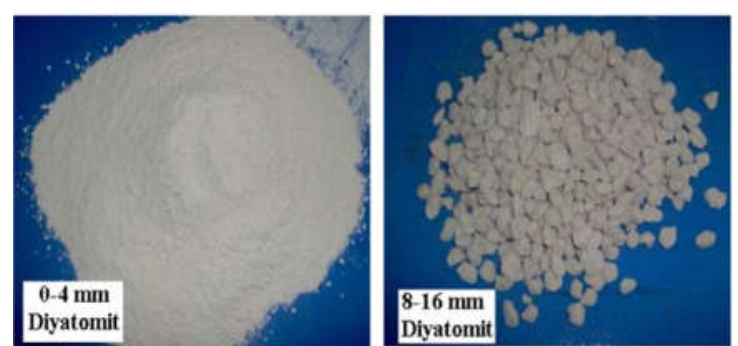

Şekil 3. Diyatomit agregası

\subsection{2. Çimento}

Karışımlarda Afyon Set Çimento A.Ş.'den temin edilen CEM I 42,5/R Portland Çimentosu kullanılmış olup, üretici firmadan temin edilen çimentoya ait kimyasal, fiziksel ve mekanik özellikler Çizelge 1'de verilmiştir [15]. 
Diyatomit Agregalı Blok Elemanların Yüksek Sicaklık ve Donma-Çözülme Etkisinde Bazı Fiziko-Mekanik Özelliklerinin Araştırılması

Çizelge 1. CEM I 42,5/R Portland çimentosu özellikleri

\begin{tabular}{|c|c|c|c|c|}
\hline Analiz Gurubu & \multicolumn{2}{|c|}{ Deney } & Sonuç & Sınır Değer \\
\hline \multirow{5}{*}{$\begin{array}{l}\text { Kimyasal } \\
\text { Özellikler }\end{array}$} & \multicolumn{2}{|c|}{$\mathrm{SO}_{3}(\%)$} & 2,91 & $<3,5$ \\
\hline & \multicolumn{2}{|c|}{$\operatorname{MgO}(\%)$} & 2,33 & $<5,0$ \\
\hline & \multicolumn{2}{|c|}{ A.Z. $(\%)$} & 1,92 & $<4,0$ \\
\hline & \multicolumn{2}{|c|}{$\mathrm{Cl}(\%)$} & 0,06 & $<0,1$ \\
\hline & \multicolumn{2}{|c|}{ Çözünmeyen kalıntı (\%) } & 0,67 & $<1,5$ \\
\hline \multirow{9}{*}{ Fiziksel Özellikler } & \multicolumn{2}{|c|}{ Kivaml1l1k suyu (\%) } & 30 & \\
\hline & \multicolumn{2}{|c|}{ Özgül yüzey $\left(\mathrm{cm}^{2} / \mathrm{gr}\right)$} & 3685 & $>3500$ \\
\hline & \multirow{2}{*}{ Piriz süresi } & Başlama (saat-dak.) & 2 sa..52 dak. & $>1$ sa. \\
\hline & & Sonu (saat-dak.) & 4 sa..36 dak. & $<10 \mathrm{sa}$ \\
\hline & \multirow{2}{*}{ İncelik } & No.70'de kalan (\%) & 0,13 & \\
\hline & & No.200'de kalan (\%) & 3,15 & \\
\hline & \multicolumn{2}{|c|}{ Özgül Ağırlık $\left(\mathrm{kg} / \mathrm{dm}^{3}\right)$} & 3,07 & \\
\hline & \multirow{2}{*}{$\begin{array}{c}\text { Basınç Dayanımı } \\
\left(\mathrm{N} / \mathrm{mm}^{2}\right)\end{array}$} & 2 gün & 26,5 & $>20$ \\
\hline & & 7 gün & 38,7 & $>31,5$ \\
\hline
\end{tabular}

\subsection{Karışımların Hazırlanması}

Blok üretimde kullanılacak diyatomit agregalarının maksimum tane çapı $16 \mathrm{~mm}$ olarak seçilmiştir. $\mathrm{Su}$ /çimento oranı: 0,15 ve çimento dozajı 220 $\mathrm{kg} / \mathrm{m}^{3}$ olarak belirlenmiş olup, sertleşmiş numuneler üzerinde yapılacak deneyler için

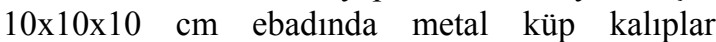
kullanılmıștır.

Karışım hesapları TS 3234'de belirtilen esaslara göre yapılmış olup, blok eleman üretimi kollu briket makinesi kullanılarak gerçekleştirilmiştir [16]. Karışıma girecek diyatomit agregası üzerinde birim hacim ağırlık, su emme ve porozite oranı değerleri belirlenmiş olup elde edilen sonuçların literatürdeki çalışmalarda $[6,19]$ belirtildiği gibi yüksek olduğu görülmektedir (Çizelge 2).

Karışım harcı Ø $630 \mathrm{~mm}$ x $330 \mathrm{~mm}$ ebatlarında, $110^{\circ}$ yatırılabilinir, 60 devir/dak. dönüş hızına sahip mikser kullanılmış olup, karışım harcının kıvamı ve çimentonun hidratasyonu için gerekli suyun agrega tarafından emilmesini engellemek amacı ile agregalar önce $30 \mathrm{dk}$. su içerisinde bekletme işlemini takiben, $30 \mathrm{dk}$. süzdürüldükten sonra karışıma eklenmiştir.

Çizelge 2. Diyatomit agregası özellikleri

\begin{tabular}{|c|c|c|c|c|}
\hline \multicolumn{2}{|c|}{ Agrega Özellikleri } & \multicolumn{3}{|c|}{ Diyatomit } \\
\cline { 3 - 5 } \multicolumn{2}{|c|}{} & $\begin{array}{c}16-8 \\
\mathrm{~mm}\end{array}$ & $\begin{array}{c}8-4 \\
\mathrm{~mm}\end{array}$ & $\begin{array}{c}4-0 \\
\mathrm{~mm}\end{array}$ \\
\hline $\begin{array}{c}\text { Birim } \\
\text { Hacim } \\
\text { Ağırlık } \\
\left(\mathrm{kg} / \mathrm{m}^{3}\right)\end{array}$ & Gevşek & 0,65 & 0,68 & 0,82 \\
\cline { 2 - 5 } & S1k1ş1k & 0,75 & 0,82 & 0,94 \\
\hline \multicolumn{2}{|c|}{ Porozite (\%) } & 38,7 & 39,1 & - \\
\hline \multicolumn{2}{|c|}{$\begin{array}{c}\text { Su Emme (\%) } \\
\text { 24 saat }\end{array}$} & 24 & 27 & - \\
\hline
\end{tabular}

Çizelge 3. Agrega karışım oranları

\begin{tabular}{|l|c|c|c|}
\hline & $\begin{array}{c}16-8 \mathrm{~mm} \\
\text { (iri) }\end{array}$ & $\begin{array}{c}8-4 \mathrm{~mm} \\
\text { (orta) }\end{array}$ & $\begin{array}{c}4-0 \mathrm{~mm} \\
\text { (ince) }\end{array}$ \\
\hline Seri - I & $\% 20$ & $\% 40$ & $\% 40$ \\
\hline Seri - II & $\% 20$ & $\% 35$ & $\% 45$ \\
\hline Seri - III & $\% 20$ & $\% 30$ & $\% 50$ \\
\hline Seri - IV & $\% 20$ & $\% 25$ & $\% 55$ \\
\hline Seri - V & $\% 20$ & $\% 20$ & $\% 60$ \\
\hline
\end{tabular}


Çimento miktarı $220 \mathrm{~kg} / \mathrm{m}^{3}$ ve su/çimento oranı: 0,15 sabit alınarak Çizelge 3'de belirtilen oranlarda agrega kullanılarak 5 farklı tane dağılım (granülometri) oranına sahip küp numuneler üretilmiştir.

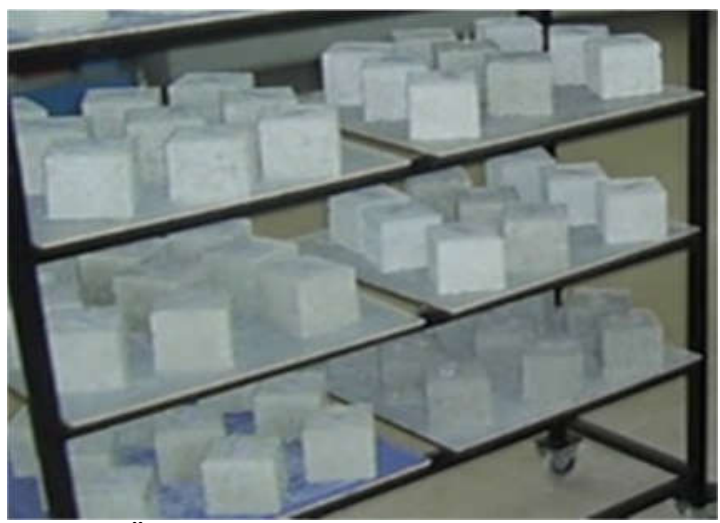

Şekil 4. Üretilen numunelerin havada kür ediliși

Üretilen numuneler 24 saat sonra kalıptan çıkarılmış ve laboratuvar ortamında $\left(20 \pm 5^{\circ} \mathrm{C}\right) 28$ gün boyunca havada kür uygulanmıştır (Şekil 4).

Diyatomit agregası ile üretilen bloklarda yüksek sıcaklık etkisini belirlemek amacıyla yüksek sicaklık testi uygulanmıştır. $\mathrm{Bu}$ test için etüv kurusu $\left(105{ }^{\circ} \mathrm{C}\right)$ numuneler önceden 1sitılmış $600{ }^{\circ} \mathrm{C}$ 'deki firına konularak, 2 saat süre ile yüksek ısıya maruz bırakılmıştır (Şekil 5).

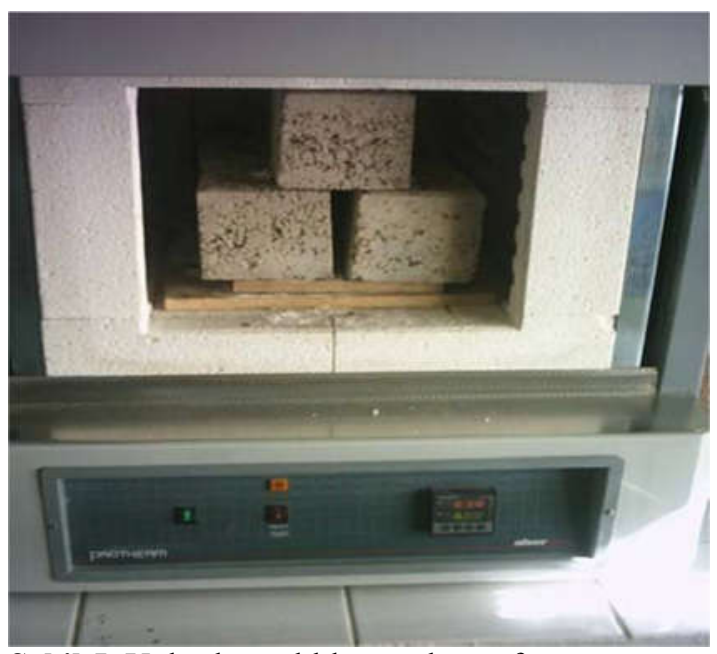

Şekil 5. Yüksek sıcaklık uygulanan firın
Laboratuvar ortamında soğuyan numuneler terazi ile tartılarak deney öncesi ve sonrası ağırlıkları kaydedilmiştir. Numuneler daha sonra ultrases hızı ve basınç dayanımı testlerine tabi tutulmuştur.

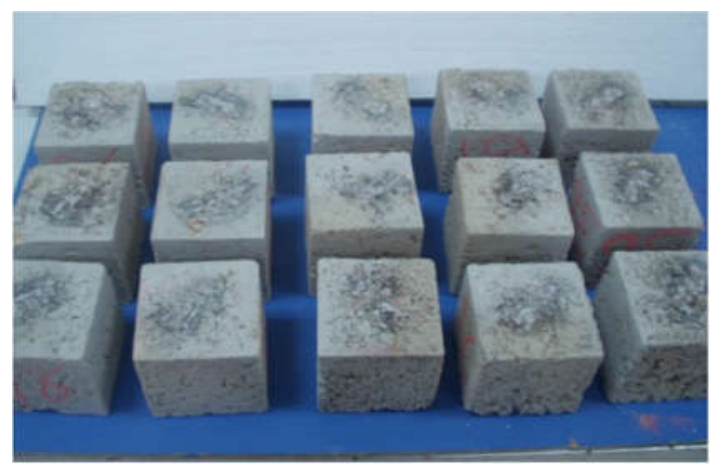

Şekil 6. Yüksek sıcaklık sonrası numunelerin genel görünümü

Laboratuvar ortamında $\left(20 \pm 5{ }^{\circ} \mathrm{C}\right) 28$ gün süre ile havada kür edilmiş numunelerin donma-çözülmeye karşı fiziksel ve mekanik özelliklerinin belirlenmesi amacıyla donma-çözülme periyodu uygulanmıştır. Etüv kurusu $\left(105{ }^{\circ} \mathrm{C}\right)$ numuneler 24 saat su içerisinde bekletilerek tamamen suya doygun hale getirilmiştir. Suya doygun haldeki deney numuneleri tüm yüzeylerinin soğuk hava ile teması eşit olabilecek şekilde $-20{ }^{\circ} \mathrm{C}$ 'deki derin dondurucu içerisinde 2 saat bekletilmiştir. Sonraki aşamada derin dondurucudan alınan numuneler +20 ila $+15{ }^{\circ} \mathrm{C}$ deki su dolu havuzda 1 saat bekletilerek çözülmeleri sağlanmıştır. Toplam 3 saat süren periyotlar (Şekil 7) sıralı olarak izlenerek donma-çözülme gerçekleştirilmiştir $[3,17]$.

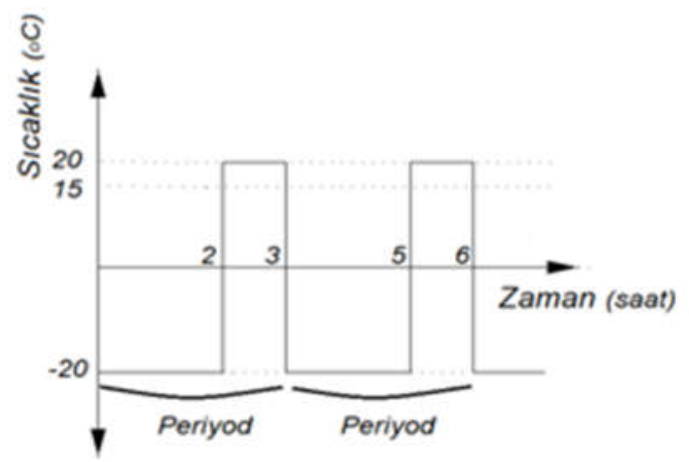

Şekil 7. Uygulanan donma-çözülme periyodu 
Diyatomit Agregalı Blok Elemanların Yüksek Sicaklık ve Donma-Çözülme Etkisinde Bazı Fiziko-Mekanik Özelliklerinin Araştırılması

Donma-çözülme işlemi 30 periyot olarak planlamasına rağmen, numunelerde görülen dağılma, dökülme ve ufalanma sonrası, deney 15. periyotta sonlandırılmıştır. Numunelerin donma-çözülme deneyi öncesi ve sonrası numunelerin görünüşleri Şekil 8 ve Şekil 9'da görülmektedir.

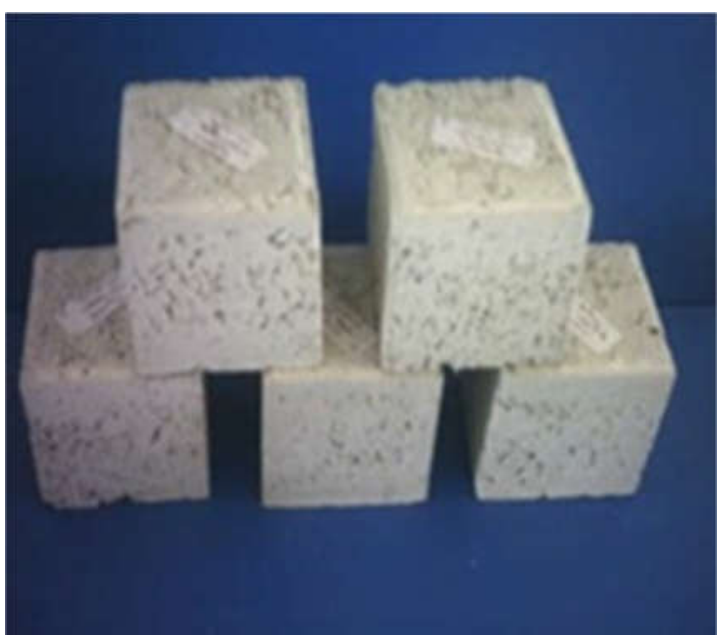

Şekil 8. Donma-çözülme öncesi numuneler
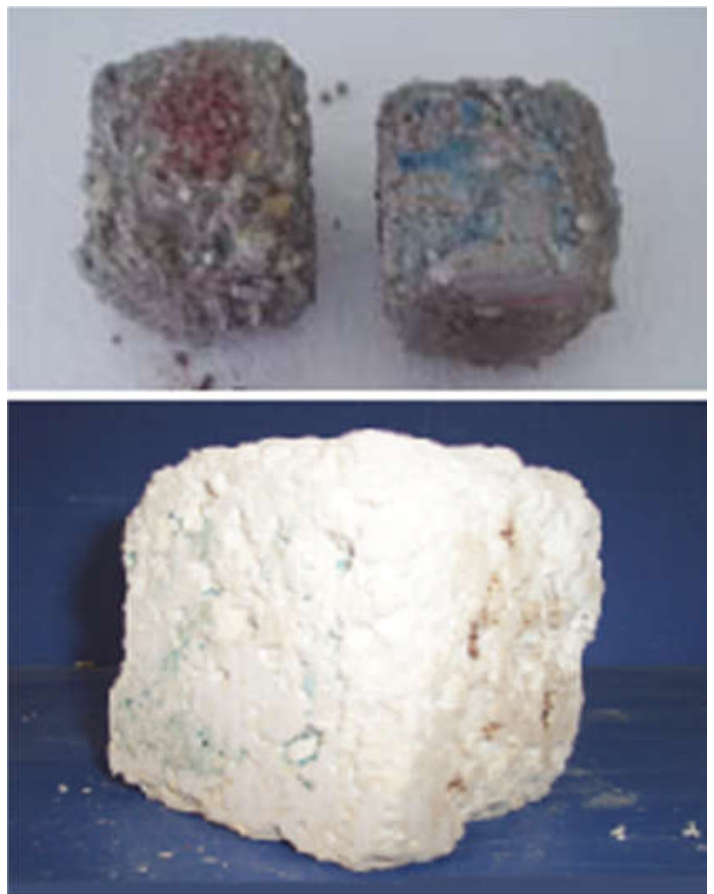

Şekil 9. Donma-çözülme sonrası numuneler

\section{BULGULAR VE TARTIŞMA}

Çalışmada üretilen diyatomit agregalı blok elemanlar üzerinde yapılan birim hacim ağırlık, porozite, ultrases, basınç dayanımı ve elastisite modülü değerleri belirlenmiş, deney sonuçlarına ilişkin veriler Çizelge 4 ve Çizelge 5'de sunulmuştur.

Çizelge 4. Blok elemanlara ait fiziksel özellikler

\begin{tabular}{|c|c|c|c|}
\hline \multirow{2}{*}{} & \multicolumn{3}{|c|}{ Havada Kür Edilen } \\
\cline { 2 - 4 } & $\begin{array}{c}\text { B.H.A. } \\
\left(\mathrm{kg} / \mathrm{m}^{3}\right)\end{array}$ & $\begin{array}{c}\text { Porozite } \\
(\%)\end{array}$ & $\begin{array}{c}\text { Ultrases } \\
\text { Hiz1 } \\
(\mathrm{km} / \mathrm{sn})\end{array}$ \\
\hline Seri - 1 & 1224 & 34,80 & 1,78 \\
\hline Seri - 2 & 1273 & 30,98 & 1,92 \\
\hline Seri - 3 & 1182 & 34,59 & 1,55 \\
\hline Seri - 4 & 1227 & 32,16 & 1,73 \\
\hline Seri - 5 & 1244 & 32,84 & 1,76 \\
\hline
\end{tabular}

28 gün havada kür edilmiş numunelerin birim hacim ağırlık değerlerinin 1182-1273 kg/m arasında değiștiği görülmektedir. Genel olarak Seri-1'den, Seri-5'e doğru gidildikçe, ince malzeme miktarının artmasına bağlı olarak, birim hacim ağırlık değerinde artış olduğu, porozite değerinin azalmasından da anlaşılmaktadır. Numunelerin porozite oranı \%30,98-34,80 mertebesindedir.

Çizelge 5. Blok elemanlara ait mekanik özellikler

\begin{tabular}{|c|c|c|}
\hline \multirow{2}{*}{} & \multicolumn{2}{|c|}{$\begin{array}{c}\text { Havada Kür Edilen } \\
\text { 28 Günlük Numuneler }\end{array}$} \\
\cline { 2 - 3 } & $\begin{array}{c}\text { Basıç̧ Dayanımı } \\
(\mathrm{MPa})\end{array}$ & $\begin{array}{c}\text { Elstisite Modülü } \\
(\mathrm{MPa})\end{array}$ \\
\hline Seri - 1 & 2,91 & 3662,80 \\
\hline Seri - 2 & 4,28 & 3984,71 \\
\hline Seri - 3 & 2,72 & 3230,31 \\
\hline Seri - 4 & 3,56 & 3746,17 \\
\hline Seri - 5 & 3,09 & 3588,68 \\
\hline
\end{tabular}

Basınç dayanımı değerleri en küçük 2,72 MPa ile Seri-3, en büyük değeri ise 4,28 $\mathrm{MPa}$ ile Seri-2 numunelerde olduğu görülmektedir. 
Diyatomit agregası kullanılarak üretilen bloklarda görülen utrases hızının 1,55-1,92 km/s arasında değişiklik gösterdiği belirlenmiştir. Basınç dayanımı, birim ağırlık, ultrases hızı ve elastisite modülü değerleri birlikte değerlendirildiğinde, en yüksek değerlerin, en yüksek birim hacim ağırlığa sahip numune serisi olan Seri-2 de, en küçük değerin ise yine en küçük birim hacim ağırlık değerine sahip olan Seri-3 numunelerden elde edilmiştir (Çizelge 4 ve Çizelge 5). Normal betonlarda görülen bu ilişkiye, diyatomit agregalı blok elemanlarda da rastlanmaktadır.

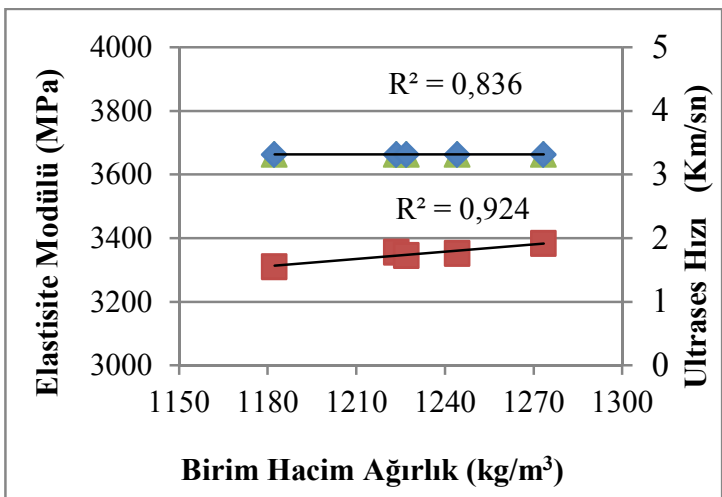

Şekil 10. B.H.A-Elastisite modülü-ultrases hızı ilişkisi

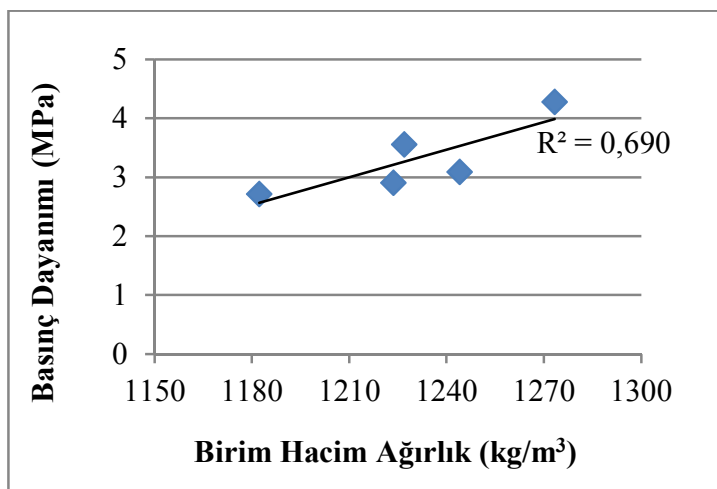

Şekil 11. B.H.A - basınç dayanımı ilişkisi

Birim hacim ağırlık-elastisite modülü arasındaki ilişki 0,836 korelasyon katsayısı ile Birim hacim ağırlık-ultrases hızı arasındaki ilişki 0,924 ve birim hacim ağırlık-basınç dayanımı arasındaki ilișki ise 0,690 korelasyon katsayısı ile lineer bir ilişki olduğu Şekil 10 ve Şekil 11'de görülmektedir.
Üretimi gerçekleştirilmiş aynı serideki diyatomit agregalı blok elemanların yüksek sıcaklık (yangın) sonrası fiziko-mekanik özelliklerindeki değişiklikleri izleyebilmek için yüksek sıcaklık testi uygulanmış ve elde edilen sonuçlar Çizelge 6'da verilmiştir.

Çizelge 6. 28 yükssek sıcaklık test sonuçları

\begin{tabular}{|l|c|c|c|c|}
\hline & \multicolumn{4}{|c|}{$\begin{array}{c}\text { Yüksek S1caklık Etkisi } \\
(28 \text { Günlük Numuneler })\end{array}$} \\
\cline { 2 - 5 } & $\begin{array}{c}\text { B.H.A } \\
\left(\mathrm{kg} / \mathrm{m}^{3}\right)\end{array}$ & $\begin{array}{c}\text { Kütle } \\
\text { Değişimi } \\
(\%)\end{array}$ & $\begin{array}{c}\text { Ultrases } \\
\text { Hızı } \\
(\mathrm{km} / \mathrm{sn})\end{array}$ & $\begin{array}{c}\text { Basınç } \\
\text { Dayanım } \\
\text { Değişimi } \\
(\%)\end{array}$ \\
\hline Seri - 1 & 1108 & $-7,39$ & 4,42 & 51,89 \\
\hline Seri - 2 & 1162 & $-7,50$ & 6,57 & 53,50 \\
\hline Seri - 3 & 1105 & $-7,32$ & 3,10 & 13,97 \\
\hline Seri - 4 & 1147 & $-8,26$ & 5,80 & 62,92 \\
\hline Seri - 5 & 1173 & $-9,16$ & 5,99 & 93,85 \\
\hline
\end{tabular}

Yüksek sıcaklık etkisinden sonra tüm serilerdeki numunelerde kütle kaybı oluşmaktadır. Kayıp oranı \%7,32-9,16 oranında değişmektedir. Basınç dayanımı değerlerinde ise ortalama \% 55,22'lik bir artış gözlemlenmiştir. Bahse konu artış çok yüksek görünse de, aynı serideki referans numunelerden elde edilen basınç dayanımı değerlerinde dahi \%25-30 mertebesinde sapmalara rastlanmıștır. Ancak basınç dayanımı ve ultrases hızı birlikte değerlendirildiğinde (Çizelge 6) yüksek sıcaklık sonrası tüm serilerde belirgin derecede artış görülmektedir. Literatürde [18-21] diyatomitin özelliklerinin sıcaklığın artışına bağlı olarak olumlu yönde değişiklik gösterdiğine dair çalışmalar mevcuttur.

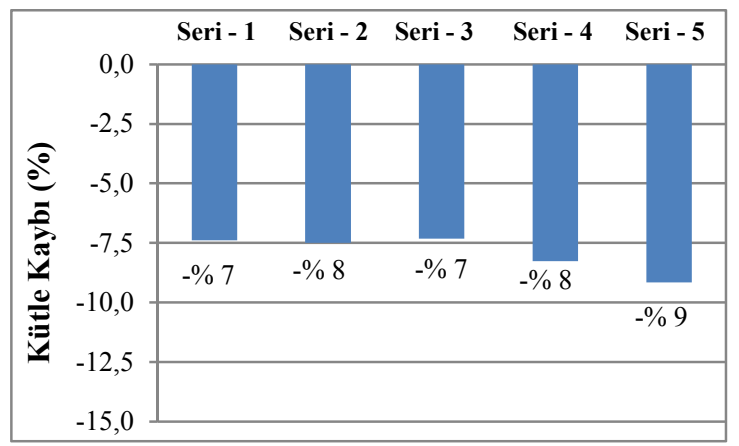

Şekil 12. Yüksek sıcaklık sonrası serilerde oluşan kütle değişimi oranı 


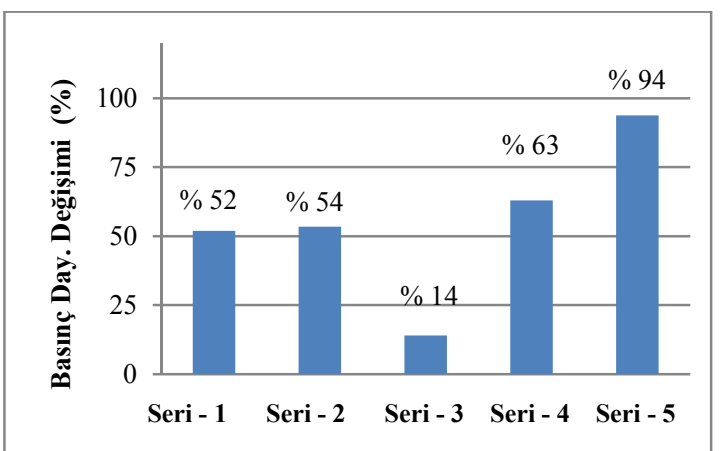

Şekil 13. Yüksek sıcaklık sonrası serilerde oluşan basınç dayanımı değişimi oranı
Ülkemizin büyük kısmında kış ikliminin görülüyor olması ve bu etkinin üretilen hafif blokların özelliklerine nasıl bir etki yaptığının belirlenmesi amaciyla, numuneler donma-çözülme periyoduna tabi tutulmuştur.

Hedeflenen donma-çözülme periyoduna (30 periyot) ulaşılamadan numunelerde gözle görülen ufalanma ve parçalanma sebebiyle (Şekil 9) deney 15. periyotta sonlandırılmıştır. Numuneler üzerinde yapılan deney sonuçlarından elde edilen kütle kaybı, ultrases hızı ve basınç dayanımı değerleri Çizelge 7'de verilmiştir.

Çizelge 7. Donma-çözülme testi sonuçları

\begin{tabular}{|c|c|c|c|c|}
\hline & \multicolumn{4}{|c|}{ Donma - Çözülme Etkisi (28 Günlük Numuneler) } \\
\cline { 2 - 5 } & $\begin{array}{c}\text { B.H.A } \\
\left(\mathrm{kg} / \mathrm{m}^{3}\right)\end{array}$ & $\begin{array}{c}\text { Kütle Değişimi } \\
(\%)\end{array}$ & $\begin{array}{c}\text { Ultrases H1zı } \\
(\mathrm{km} / \mathrm{sn})\end{array}$ & $\begin{array}{c}\text { Basınç Dayanım Değişimi } \\
(\%)\end{array}$ \\
\hline Seri - 1 & 1097 & $-5,62$ & 3,50 & 20,10 \\
\hline Seri - 2 & 1154 & $-5,21$ & 3,98 & $-7,01$ \\
\hline Seri - 3 & 1084 & $-23,27$ & ------ Yapılamadı & ------ Yapılamadı \\
\hline Seri - 4 & 1144 & $-5,69$ & 2,95 & $-17,28$ \\
\hline Seri - 5 & 1147 & $-2,87$ & 2,95 & $-4,53$ \\
\hline
\end{tabular}

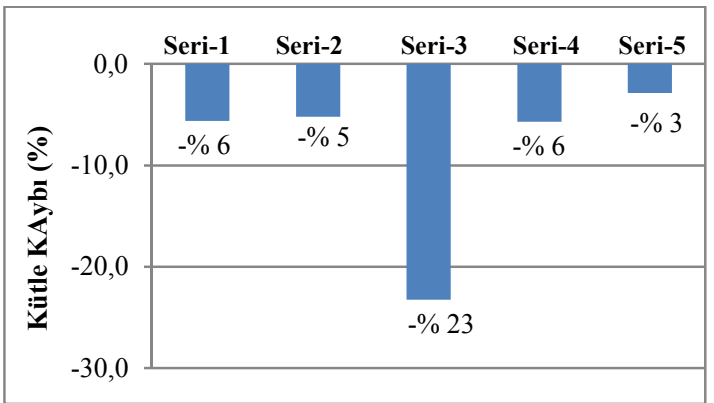

Şekil 14. Donma-çözülme sonrası serilerde oluşan kütle değişimi oranı

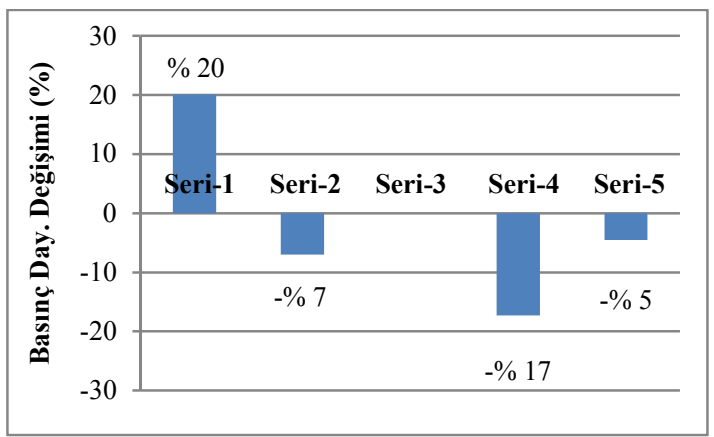

Şekil 15. Donma-çözülme sonrası serilerde oluşan basınç dayanımı değişimi oranı donmaçözülme deneyi sonrasında genel olarak tüm serilerde kütle kaybı ve basınç dayanımı değişimi yaşandığı söylenebilir. Seri-1 deki basınç dayanımı artışının üretim kaynaklı bir problemden oluşabileceği düşünülmektedir. Serilerde ortalama kütle kaybının \%8,53 değerinde olduğu Şekil 7'de görülmektedir. [19,22]. Seri-3 numunelerde görülen \%23'lük kütle kaybı sebebiyle bu seri numunelerde ultrases ve basınç dayanımı değerleri elde edilememiştir.

\section{SONUÇLAR}

- Diyatomit kayacinı hafif blok eleman üretiminde kullanılabilirliği ve özellikle yüksek sıcaklık ve donma çözülme etkisi altındaki fiziksel değişimlerinin araştırıldığ 1 bu çalışmada 28 günlük numuneler üzerinde yapılan deney sonuçlarından elde edilen verilere göre;

- Üretilen blokların birim hacim ağırlık değerlerinin $\quad 1080-1280 \quad \mathrm{~kg} / \mathrm{m}^{3} \quad$ arasında 
değişiklikler gösterdiği, birim hacim ağırlıkelastisite modülü ve birim hacim ağırlıkultrases hizı arasında sirasiyla 0,836 ve 0,924 korelasyon katsayısı ile lineer bir ilişki bulunmuştur. Ancak basınç dayanımı, elastisite modülü ve utrases değerlerinde benzer bir ilişkiye rastlanmamıştır.

- Yüksek sicaklığa maruziyet sonrası kütle kaybının ortalama \%-7,92 değere ulaşılmasına rağmen, basınç dayanımı değerinde ortalama \%55,22'lik bir artış gözlenmiştir.

- Donma-çözülme etkisi incelendiğinde, numunelerde ufalanma, dağılma ve parça kopmalarının gözle görülür seviyede ve ortalama kütle kaybının $\% 8,53$ oranında olduğu, basınç dayanımı değerlerinde ise genel olarak azalma görülmesine rağmen doğrusal bir ilişkiye rastlanmamıştır.

- Sonuç olarak diyatomit agregası kullanılarak üretilecek blok elemanların yüksek sıcaklık ile fiziksel özelliklerinde olumlu yönde değişiklikler görülmesine rağmen, donmaçözülme periyotları sonrasında numunelerde önemli derecede kütle kaybı (ufalanma, parçalanma) ve basınç dayanımı değerinde önemli ölçüde düşüş olduğu tespit edilmiştir.

- Numunelerden elde edilen basınç mukavemeti değerlerinin 2-6 $\mathrm{MPa}$ aralığında değişiklik gösterdiği, bu sebeple yük taşımayan bölme duvar elemanı piyasadaki benzer malzemelere alternatif olarak kullanılabilen, boşluklu yapıya sahip olması sebebiyle de yalıtım malzemesi olarak değerlendirilebileceği sonucuna ulaşılmıştır. Benzer özellikteki doğal yapıtaşları ile farklı karışımlar yapılarak, zayıf olan özelliklerin belli oranda iyileştirilmesi sağlanabilecektir.

\section{KAYNAKLAR}

1. Temiz, H., Akçekale, A.H., 2014. Hafif Agregalı Betonun Mühendislik Özelliklerinin Araştırılması. Karaelmas Fen ve Mühendislik Dergisi, 4(2), 7-20.
2. Mouli., M., Khelafi, H., 2008. Performance Characteristics of Lightweight Aggregate Concrete Containing Natural Pozzolan, Building and Environment, 43, 31-36.

3. Güçlüer, K., Ünal, O., Demir, İ., 2014. Buhar Kürlü Gazbetonun Mekanik ve Fiziksel Özelliklerine Puzolan Katkısının Etkisi, Afyon Kocatepe Üniversitesi Fen ve Mühendislik Bilimleri Dergisi, 14,(1), 1-6.

4. Serin, G., Cankıran, O., Başyiğit, C., Taş, H.H., Fenkli, M., 2007. Normal, Hafif ve Yarı Hafif Beton Blokların Fiziksel ve Mekanik Özelliklerinin Karşılaştırılması, Teknolojik Araştırmalar: YTED (1) 15-22.

5. Yasar, E., Atis, C.D., Kilic, A., Gulsen, H., 2003. Strength Properties of Lightweight Concrete Made with Basaltic Pumice and Fly Ash, Materials Letters, 57, 2267- 2270.

6. Gökçe, M.V., 2010. Diyatomit Esaslı Hafif Yap1 Elemanı Üretiminde Üre-Formaldehitin Bağlayıcı Olarak Kullanılması, Doktora Tezi, Selçuk Üniversitesi, Fen Bilimleri Enstitüsü, 131, Konya, Türkiye.

7. Gündüz, L., Sarışık, A., Tozaçan, B., Davraz, M., Uğur, İ., Çankıran, O., 1998. Pomza Teknolojisi. Cilt- I, Süleyman Demirel University, 275-285.

8. Akbaba, H., 2007. Agrega Türünün Hafif Blokların Özelliklerine Etkisinin Araştırılması, Yüksek Lisans Tezi, Afyonkarahisar Kocatepe Üniversitesi, Fen Bilimleri Enstitüsü, Afyonkarahisar.

9. Meisinger, A.C., 1984. Diyatomite, Çeviren I. Işık, Anadolu Üniversitesi Müh.-Mim. Fak. Dergisi, 1(2), 141-158.

10. Lydon, F.D., 1992. Concrete Mix Design, Applied Science Publishers, $2^{\text {nd }}$ ed., London.

11. Borat, M., 1992. Türkiye Diyatomitlerinin Özellikleri ve Filtrasyon Karakteristikleri, Doktora Tezi., İTÜ, Fen Bilimleri Ens., 131. İstanbul.

12. Yıldırım, A.N,. 2007. Pomza ve Uçucu Kül Kullanılarak İmal Edilen Hafif Betonların Agresif Su Ortamlarında Mekanik Özelliklerinin Araştırılması, Yüksek Lisans Tezi, Selçuk Üniversitesi, Fen Bilimleri Enstitüsü, 121, Konya.

13. Aruntaş, H.Y., Albayrak, M., Saka, H.A., Tokyay, M., 1998. Ankara-Kizilcahamam ve 
Diyatomit Agregalı Blok Elemanların Yüksek Sicaklık ve Donma-Çözülme Etkisinde Bazı Fiziko-Mekanik Özelliklerinin Araştırılması

Çankır1-Çerkeş Yöresi Diyatomitlerinin Özelliklerinin Belirlenmesi, Turkey J. of Engineering and Environmental Science, 22, 337-343.

14. TS 706 EN 12620, Beton Agregalar1, Türk Standartları Enstitüsü, Ankara, 2009.

15. TS EN 197-1: 2012 - Çimento- Bölüm 1: Genel Çimentolar Bileşim, Özellikler ve Uygunluk Kriterleri.

16. TS 3234., Bims Beton Yapım Kuralları, Karışım Hesabı ve Deney Metotları; Türk Standartları Enstitüsü; Ankara, Eylül 1978.

17. TS 3449, Çabuk Donma ve Çözülme Koşulları Altında Betonda Dayanıklılık Faktörü Tayini. Türk Standartları Enstitüsü, Ankara, 1980.

18. Posi, P., Lertnimoolchai, S., Sata, V., Phoongernkham, T., Chindaprasirt, P., Investigation of Properties of Lightweight Concrete with Calcined Diatomite Aggregate. KSCE Journal of Civil Engineering, 18(5), 1429-1435.

19. Bideci, A., Bideci, Ö., 2016. Diatomit Hammaddesinin Tuğla Üretiminde Kullanılabilirliğinin Araştırılması. Trakya Üniversitesi Fen Bilimleri Dergisi, 9(2), 76-69.

20. Ceylan, H., Saraç, M.S., 2006. Farklı Pomza Agrega Türlerinden Elde Edilen Hafif Betonun Sicaklık Etkisindeki Bazı Özellikleri Üzerine Bir Araştırma, Süleyman Demirel Üniversitesi, Fen Bilimleri Enstitüsü Dergisi, 10(3), 413-421.

21. Degirmenci, N., Y1lmaz, A., 2009. Use of Diatomite as Partial Replacement for Portland Cement in Cement Mortars Construct Build Mater, 23, 284-288.

22. Ergün, A., 2011. Effects of the Usage of Diatomite and Waste Marble Powder as Partial Replacement of Cement on the Mechanical Properties of Concrete, Construction and Building Materials, 25(2), 806-812. 